\title{
Identification, Prioritization and Management of Construction Project Claims
}

\author{
B. Dastyar ${ }^{1}$, A. F. Esfahani ${ }^{2}$, M. Askarifard ${ }^{3}$, and A. Monir Abbasi ${ }^{4}$ \\ ${ }^{1}$ MSc student, Department of Civil Engineering, Faculty of Engineering, Karaj Payam Noor University, Iran, Bagher. \\ Email: dastyar@gmail.com (corresponding author). \\ ${ }^{2}$ MSc student, Department of Civil Engineering, Faculty of Engineering, Amirkabir University of Technology, Iran. \\ Email: amir_fkh110@yahoo.com \\ ${ }^{3} \mathrm{PhD}$ student, Arak Azad University, Arak, Iran. Email: M_askarifard@aut.ac.ir \\ ${ }^{4}$ Assistant Professor, Department of Civil Engineering, Payam Noor University, Iran. Email: MonirAbbasi@pnu.ac.ir
}

Project Management

Received January 7, 2018; received revisions March 31, 2018; April 20, 2018; May 29, 2018; accepted May 31, 2018

Available online June 19, 2018

\begin{abstract}
Since stakeholders of construction projects do not have full awareness about conditions, obligations, and terms of contracts or do not act upon them, problems can occur during the spam in which the project if carried out or after its finalization which leads to various claims. These claims prevent construction projects from completing and cause delay in delivery of projects or increase project cost and duration. This research investigates claims and proposes methodologies for their prioritization and management. Due to the similarities of construction projects in all over the world, this research could be found applicable in other construction projects. This research was performed based upon a statistical sample of 117 participants in construction industry and the data was collected through questionnaires. Related factors were categorized in 6 groups, consisting of: employer related conditions, factors related to contractors, subcontractors, contract documents, contractual relationships, project conditions and other factors. The questionnaire's reliability was evaluated by Cronbach's alpha and reliability of the questionnaire was confirmed. After analyzing the collected data from Friedman test, it was shown that the most important factors which have an effect on claims are: offering contractual price less than minimum tender price, contractor's financial problems, lack of materials and their inflated prices. Finally, as a result of this research, recommendations were provided for reducing claims and preventing them from occurring on construction industry. Limited research exists on this subject. Moreover, a remarkable flaw with previous studies has been a lack of appropriate questionnaires. This study had been promoted according to field studies of authors.
\end{abstract}

Keywords: Claim, delay, construction, conflict management, construction industry, project management.

\section{Introduction}

The construction industry is one of the most important drivers of any economy. Most of the ongoing projects usually suffer from weak management techniques which generally lead to delay resulting in higher costs, lower quality, customer dissatisfaction, safety level reduction, etc. Therefore, efforts for finishing projects in the estimated time period, at the least cost and highest level of quality, safety and satisfaction of customers, brings up many problems for managers and engineers of construction projects in which case claims become inevitable (Sheikh et al., 2006). Additionally, as a result of higher uncertainty and complexity in construction projects, claims and legal issues follow an ascending trend (Hackett and Dancaster, 2000). Some of the most important reasons which lead to the claims are as follows, error in the original cost estimate of the project, risk of unpredicted events and accidents, changes in construction contract and its management, changes to current stakeholders of the project (Qi, 2004; Chang, 2005; Kartam, 1999). Claims occur when one of the contractual parties faces loss or damage which can be compensated by other parties (Vidogah and Ndekugeri, 1997). All member of the project, including employer, designer, and contractor must have a complete understanding about the phases of a claim settlement. Project agents' unawareness, incorrect contract planning, and other factors will cause further losses to the whole project (Singh et al., 2006; Surawongsin, 2002). Most of the project's participants consider claims as undesirable side effects. These claims cause the project to recede from its main objectives. Analysis of different types of claims and their justifications is one the most significant steps in the process of resolving project claims.

The construction industry needs to identify and prioritize claims and create techniques which can be utilized for reduction of project claims. Claims are usually divided into six categories including main 
contractual claims, delay claims, acceleration claims, change claims, extra working claims, and different site condition claims. Claims are an inseparable part of contracts and their occurrence on projects is considered normal (Bradley and Langford, 1987). Since the project participants are aware of the high costs and risks related to claims, the construction industry needs to develop techniques which might be functional in reducing claims or preventing them as much as possible, although claims have a continuous presence particularly on construction projects (Barrie and Paulson, 1992; Diekman and Nelson, 1985). Managing construction claims is an important challenge in the construction industry, that lots of contractors are dealing with currently. These claims lead to project delays and secondary problems in the construction industry. Therefore, it is necessary to improve methods to manage construction claims more efficiently and resolve current problems in this field (Kululanga et al., 2001). Claim management is a very important subcategory of project management. The most important principle in managing claims is to be completely aware of the conditions, terms and clauses of the contract. In other words, full evaluation of the ability of contracts for legal prosecutions is only possible through reading out the content of contract carefully and comparing it with realities that have happened in the project such as changing in scope, cost, time, quality, etc.

Hence, it can be argued that the main reason for performing claim analysis is the fact that disagreements overshadow any teamwork, decrease members' motivation and are a potential factor for lower trustworthiness among them. The development and dominance of such mindset among project participants has a considerable negative impact on their collaborative attitude, so it is really important to propose approaches which can prevents any potential claim occurrence in a project or create a powerful procedure to guide people through it (Project management institute, 2010). Claim management is a process which controls the claims and acts as a lever which prevents the contract's content from further unpredicted changes by both parties. Having an efficient construction claim management procedure is mandatory in current situation since the number of claims has been growing significantly. Optimal claim management improves operational capacity of projects and play an important role in efficient project management. Effective claim management also analyzes and controls any increases in the project's time and cost which are the outcomes of claims in construction projects (Chovichien and Tochaiwat, 2006). According to the above arguments, the occurrence of claims in contracts is inevitable and requires appropriate claim management procedures. Despite its importance the necessity of performing a comprehensive study on claim management which tries to gather expert's opinion through surveys and identifies, prioritizes and manages claims accordingly. This article had been provisioned according to the above approach.

\section{Literature Review}

Several research efforts had been done to identify causes of claims and methods to manage or reduce them. Chaphalkar et al. (2012) had predicted conflicting results about construction claims by means of Multilayer perceptron Neural Network. This investigation led to identification of several internal factors and feasibility of multilayer perceptron neural network had been also evaluated based on sources of internal conflicts. Data collected from 204 work volume change claims related to this rewarding method had been used for development of proposed model and three-layer perceptron neural network was considered suitable to build this model which requires necessary development, confirmation, and examination. Using this newly designed tool prevent any further conflict. Although this research is conceptually efficient, it does not reflect the opinion of experts.

Issa (2013) has addressed the conceptualizing claim management knowledge in construction projects. Results from the case study in this research showed that the proposed approach is deemed as "an effective framework to examine various implemented actions in this field.” This research only proposed an approach for claim management and lacks any model validation procedure. Zaneldin (2006) analyzed construction claims in the United Arab Emirates. This research proposed the results related to types, reasons, and affluence of constructional claims in the United Arab Emirates and 124 claims were used for a group of projects. Data was analyzed and results showed that the most important causes of claims include change in the project, employer's delay, and planning error. Although this research successfully identified many causes of delay in construction project in the UAE, it did not suggest any evaluation, prioritization and solution for their management. Arditi and Pattanakitchamroon (2006) selected a new method for analyzing delay and resolving construction claims. This research investigated 20 articles related to delay in the planned areas, demolition before construction, and time impact analysis.

According to superiority of time analysis technique, this method is the best in case of time claims and project managers have high level of confidence in such practices in order to create sufficient information about time analysis while confirming related requirements. This article also investigated claim evaluation methods which is a confirmation of current research gap in this field.

According to reviewed literature, it seems that there is a real need for a comprehensive study about causes of delays, their evaluation and prioritization and finally suggesting corresponding solutions to manage them based on ideas of construction industry experts. In this research, the main focus is on identification and prioritization of construction claims according to a survey of construction experts. Data acquisition and analysis from some of construction projects in Iran was necessary for performing the current research. Since there is relative similarity among construction projects all over the world, the results of current research can be used for other projects with a high level of accuracy.

\section{Scope of Research}

Required data for this research had been collected from some participants in construction projects. The data was gathered from 117 members of project teams as research's samples which are shown in Table 1 (It should be noted that the number of people in statistical population and sample in this study are equal and sampling was conducted through whole census method). The database in this study contains claims and their legal conditions in construction contracts, which had been analyzed through a survey of contractors, consultants, employers, executive managers and other members of the project. This survey 
has been performed based upon a questionnaire in which selected people answered five optional questions (fivepoint Likert scale), included levels are "1. very low," "2. low,” "3. average,” “4. high,” and “5. very high.”

Table 1. Position and level of education in respondents

\begin{tabular}{|c|c|c|c|c|c|}
\hline $\begin{array}{l}\text { Type of } \\
\text { respondents }\end{array}$ & 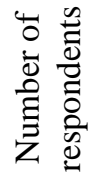 & 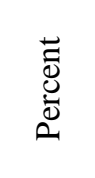 & 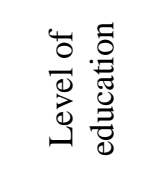 & 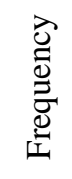 & 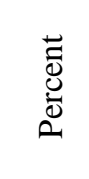 \\
\hline Contractor & 52 & $44 \%$ & $\begin{array}{c}\text { Associate } \\
\text { degree }\end{array}$ & 2 & $2 \%$ \\
\hline Consultant & 26 & $22 \%$ & BS & 50 & $43 \%$ \\
\hline Owner & 33 & $28 \%$ & MS & 58 & $50 \%$ \\
\hline $\begin{array}{l}\text { Contract } \\
\text { management }\end{array}$ & 4 & $3 \%$ & \multirow{2}{*}{$\begin{array}{l}\text { PhD and } \\
\text { higher }\end{array}$} & \multirow[t]{2}{*}{7} & \multirow[t]{2}{*}{$6 \%$} \\
\hline Others & 2 & $2 \%$ & & & \\
\hline Total & 117 & $100 \%$ & Total & 117 & $100 \%$ \\
\hline
\end{tabular}

Fig. 1 and Fig. 2 shows level of experience in construction industry and claim management units, respectively.

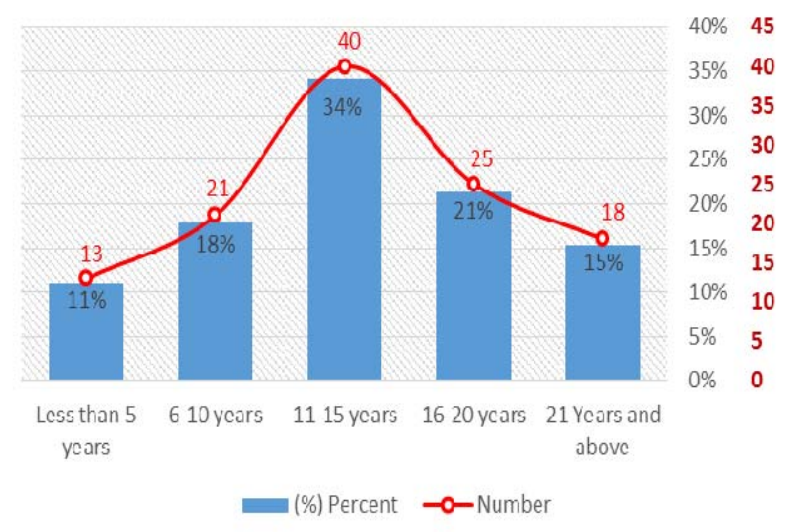

Fig. 1. Participant's level of experience in construction industry

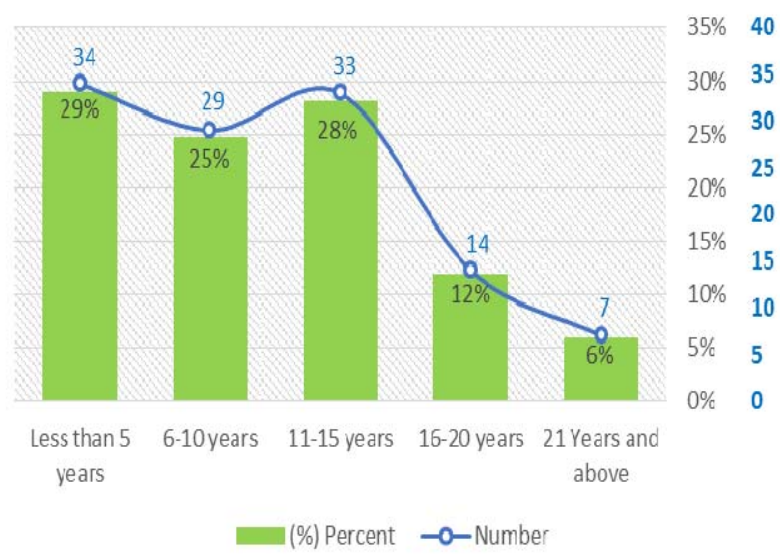

Fig. 2. Participant's level of experience in claim management unit
Collected data belongs to different types of construction projects such as residential complexes, common buildings, commercial buildings, etc. In the process of designing research questionnaire, proper indicators, literature, library resources and experts opinions were used for codification of the questionnaire which covered causes of claims and their relative importance. After confirmation of the validity by experts the questionnaires were distributed to participants for data acquisition and completion of the research process. After collecting completed questionnaires, the reliability of the questionnaire was first tested through Cronbach's alpha. Measured Cronbach's alpha was equal to 0.952 and yet the obtained value was more than the minimum acceptable value which was set at 0.7 . Therefore, the reliability of questionnaire was confirmed. Finally, the questionnaire's data were approved for further analysis. The questions were all formulated based on one of the main effective factors in Iran's construction projects and their priority were estimated through Friedman test. In addition, the probability of occurrence for each mentioned claim in questionnaire was ranked in regard to frequency of occurrence in construction projects. After determining the priority of claims, the main claim management solutions were proposed according to expert's opinions.

\subsection{Major Types of Claims and Their Frequency in Construction Projects}

The dimensions of the questionnaire were identified according to proposed questions and research literature. Major causes of claims in Iran's construction projects were divided into six categories: factors related to the employer; factors related to contractor and subcontractors; factors related to contract documents; contractual relationship factors; factors related to projects and other components (minor secondary factors). Different types of constructional contracts are shown in Table 2.

Table 2. Different types of construction contracts

\begin{tabular}{lcc}
\hline $\begin{array}{l}\text { Type of contract } \\
\text { construction project }\end{array}$ & $\begin{array}{c}\text { Number of } \\
\text { contracts }\end{array}$ & Percent \\
\hline Design and build & 15 & $13 \%$ \\
DBB & 65 & $56 \%$ \\
Performance management & 11 & $9 \%$ \\
EPC & 24 & $21 \%$ \\
BOT & 2 & $2 \%$ \\
\hline Total & 117 & $100 \%$ \\
\hline
\end{tabular}

\subsection{Different Types of Claims and Their Frequency in Construction Projects}

Opinions of project managers, contractors, consultants and experts were gathered through a questionnaire. Collected data shows that claims are divided into six groups based on the frequency of occurrence in constructional projects which are: 1 - work volume work volume change claims; 2- extra work claims; 3- delay claims; 4- claims due to changed condition; 5- request for work acceleration claims, and 6- claims due to ambiguities in contract conditions. Table 3 shows types of claims which are classified according to the frequency of occurrence in construction projects.

\section{Methodology}


Table 3. Types of claims based on frequency of occurrence in constructional projects

\begin{tabular}{lcc}
\hline Types of claims & Average & Rank \\
\hline Delay claims & 4.18 & 1 \\
Working volume change & 3.91 & 2 \\
claims & 3.91 & 2 \\
Extra work claims & 3.68 & 3 \\
Contract ambiguity claims & 2.91 & 4 \\
$\begin{array}{l}\text { Different or changed site } \\
\text { condition claims }\end{array}$ & 2.90 & 5 \\
\hline
\end{tabular}

For a reasonable estimation about frequency and type of claims, five different options related to claims had been considered and ranked from 1 to 5 . Rating 1 indicates very low and rating 5 indicates very high for frequency and type of claims. In case that respondents did not answer, no rating was allocated to answers. The mean rating for 'work volume change claims was 4.18 which is ranked in the first place in Table 3. Results of analysis show that delay claims are most noticeable claims which have the highest mean and ranking, work volume change claims and extra work claims have equal means (3.91); thus, both of them were placed in second position. Work acceleration claims have a mean rating of 2.90 which puts them in the last position of $5^{\text {th }}$.

\subsection{Ranking Major Types of Claims in Construction Projects}

The rating mean of major types of claims which have an effect on occurrence of claims in construction projects was calculated in order to make it possible for performing any further analysis and prioritization. Also, the ranking of any factor plus its related criteria had been acquired through Friedman test for available questionnaire. The results of analysis have been shown in Table 4 .

Table 4. Results of effective factors analysis

\begin{tabular}{lcc}
\hline Criteria & Ave. & Rank \\
\hline \multicolumn{3}{c}{ Major types of claims related to employers } \\
Payments delay & 3.08 & 1 \\
Employers personality & 2.2 & 4 \\
Lack of experience in employees for & 2.27 & 3 \\
managing contract rules & 2.45 & 2 \\
Delay in employers decision making & 2.00 \\
\hline \multicolumn{3}{c}{ Chi-Square: 46.779, df: 3, Asymp. Sig.: 0.000 } \\
\hline \multicolumn{3}{c}{ Major types of claims related to contractors and } \\
\multicolumn{3}{c}{ subcontractors } \\
Contractor delays & 3.73 & 2 \\
Contractor's financial problems & 4.61 & 1 \\
Unpredicted conditions by contractor & 3.41 & 3 \\
Performance error by contractor & 3.16 & 4 \\
Subcontractor's problems & 3.07 & 5 \\
Subcontractors' weak operation & 3.02 & 6 \\
quality & \multicolumn{2}{c}{6} \\
\hline \multicolumn{2}{c}{ Chi-Square: 85.429, df: 5, Asymp. Sig.: 0.000 } \\
\hline
\end{tabular}

Table 4. Results of effective factors analysis

(continued)

\begin{tabular}{|c|c|c|}
\hline Criteria & Ave. & Rank \\
\hline \multicolumn{3}{|c|}{ Major types of claim documents related to claims } \\
\hline Contract and its written ambiguities & 4.17 & 1 \\
\hline $\begin{array}{l}\text { Change in amount of performing } \\
\text { works }\end{array}$ & 4.13 & 2 \\
\hline $\begin{array}{l}\text { Design error or deleting items during } \\
\text { the work }\end{array}$ & 3.44 & 3 \\
\hline $\begin{array}{l}\text { Bill for items ,plans, and } \\
\text { contradiction in specification }\end{array}$ & 3.24 & 4 \\
\hline Different types of contracts & 2.59 & 5 \\
\hline Planning/scheduling errors & 3.44 & 3 \\
\hline
\end{tabular}

Chi-Square: 76.662, df: 5, Asymp. Sig.: 0.000

Major types of claims for impact of contractual relationships on claims

Weak cooperation among project

participants

$4.15 \quad 3$

Wrong encounter toward changes and

unpredictable results

$4.18 \quad 2$

Contract repeal from each side

(clause 46)

$3.88 \quad 5$

Job suspension (clause 49)

$3.92 \quad 4$

Offering contract with the least

tender price

$4.76 \quad 1$

Weak quality control and security factors

Change in process and regulations

(tax-free, change in tax value)

Chi-Square: 68.565, df: 6, Asymp. Sig.: 0.000

Major types of claims related project claims

Different partial term in comparison

to previous terms

$1.89 \quad 4$

Changing project's scope

$2.82 \quad 2$

Project performance complexity

$3.04 \quad 1$

Change to a new place in compare to

the previous one

$2.24 \quad 3$

Chi-Square: 82.162, df: 3, Asymp. Sig.: 0.000

Other major types of claims

Job suspension because of political

issues

Contract cancellation because of

political issues

3.09

5

Material shortage and high price

because of boycott

Border closure because of boycott

Force Majeure, war, flood, attack

Beneficiaries, interest holders, local

society, donators, officials,

3.194

$4.46 \quad 1$

$3.66 \quad 3$

$2.76 \quad 6$

interference

Chi-Square: 98.951, df: 5, Asymp. Sig.: 0.000

The rating mean for delay in payments is 3.08 which places in it at the first of effective factors related to "employer". Moreover, delay in employer's decision making has a rating mean of 2.45 which places it at the second place, "employer's personality" criterion has a weighted mean of 2.2 which places it in the last place. 
The rating mean of contractor's financial problems is 4.61 which places it at the first place of effective factors related to "contractor and subcontractors". In addition, contractor's delay has a rating mean of 3.73 which places it at the second place, "weak quality of contractor's performance" criterion has a rating mean of 3.02 which places it in the last.

The rating mean of contract and its written ambiguities is 4.17 which places it in the first ranking of effective factors related to "contract's documents". In addition, changes in planned activities has a rating mean of 4.13 which places it at the second place, "different types of contracts" criterion has a weighted mean of 2.59 which places it at the last place.

The rating mean of proposing contractual offer to the least tender price is 4.76 which places it in the first of effective factors related to "contractual relationships". Furthermore, facing changes and unpredicted results has a rating mean of 4.18 which places it at the second place, "changes in processes and regulations (tax free, changes in value of taxes)" criteria has a rating mean of 3.16 which places it in the last.

The rating mean of operational complexity is 3.04 which places it in the first of "effective factors related to projects". In addition, changes in scope of project has a rating mean of 2.82 which places it in the second place, "minor changes with respect to previous situation" criteria has a rating mean of 1.89 which places it in the last.

The rating mean of the shortage of materials and inflation because of boycotts is 4.46 which places it in the first of "other effective factors". Moreover, the "stakeholders, beneficiaries, local community, suppliers, governments, interference" criterion has a rating mean of 3.84 which places it in the second place, force major, war, flood, attack has a rating mean of 2.76 which places it in the last place.

Table 5. Calculated mean values for effective factors

related to occurrence of claims in construction projects

\begin{tabular}{lcc}
\hline Criteria & Average & Rank \\
\hline Factors related to employer & 4.86 & 1 \\
$\begin{array}{l}\text { Factors related to contract } \\
\text { documents }\end{array}$ & 4.53 & 2 \\
$\begin{array}{l}\text { Factors related to contractor and } \\
\text { subcontractor }\end{array}$ & 3.76 & 3 \\
$\begin{array}{l}\text { Contractual relationships factors } \\
\text { Factors related to project }\end{array}$ & 2.93 & 4 \\
$\begin{array}{l}\text { Other identified factors } \\
\text { (components) }\end{array}$ & 2.54 & 5 \\
\hline
\end{tabular}

Table 5 shows the estimated rating mean values for different effective factors; "factors related to employer" has a rating mean of 4.86 which places it at the first ranking, "factors related to contract's documents" has a weighted mean of 4.53 which places it a the second rank. "Other factors" criteria has a rating mean of 2.37 which places it at the last rank.

\section{Methods and recommendations for reducing- resolving claims in construction projects}

Construction projects are mostly complicated. These projects are inevitably explained by a group of plans (maps) and technical specifications; they are performed by the main contractor and some subcontractors which most of them do not have any kind of previous cooperation experience. Since each project is unique, it has its own conditions; therefore, predicting all of its aspects is impossible. Thus, some contradictions occur in contract documents and conflicts are very common in the construction industry. In general, it is possible to argue that according to the final results achieved in this study which are shown in Table 4, the most important effective factors on occurrence of claims in construction projects which are considered in different dimensions of questionnaire and estimated according to rated mean values (rankings extracted from Friedman test) are: delay in payments, contractors financial problems, contract and written ambiguities, facing changes and unpredicted results in an inappropriate manner, operational complexity and shortage of materials and inflation (higher prices) because of boycotts.

In order to prevent claims, prevailing over them and also reducing them in construction industry, the following recommendations are made according to the most important criteria defined in this study which all have a significant impact on occurrence of constructional claims and accurately extracted from experts opinions:

1. Designing of appropriate methods for controlling/monitoring of employer/ contractor's payments.

2. Providing options such as special budgets and facilities for construction projects from government, banks and transferring such projects to private contractors who have financial affordability.

3. Composing clearly and unequivocal written contract, reading contract's content repetitively in order to understand unknown clauses of contract, specifically, those related to different parties.

4. Implementing suitable strategies such as risk response or risk allocation in order to deal with changes/ predicted results in construction projects correctly and achieving maximum prevention / lowest failure rates.

5. Using proper procedures to resolve multilateral conflicts among different parties of constructional projects according to current operational complexities such as delays or occurrence of different types of risk.

6. Sufficient supply of materials from both contractor and employer in the initial steps of project and having financial ability to supply materials during project implementation in case of occurrence of any change during operational steps.

7. Recording daily, weekly or monthly report for construction project's activities in order to monitor the implementation steps and fulfill predetermined goals.

\section{Conclusion}

To draw the conclusion, management of constructional and engineering claims consists of general and systematic approaches which require knowledge and skills in fields of project management. In this research, identification, prioritization and management of construction claims have been examined through survey which was completed by means of questionnaire analysis (Friedman 
test). Results indicate that the most noteworthy type of building claims is claims related to delay in projects with mean value of 4.18. Both work volume change claims and extra work claims are placed in second, with equal mean of 3.91 and acceleration of work claims are placed in the last position with a mean rating of 2.90 . It is also noteworthy to mention that the major types of claims are causes related to the employer with a mean of 4.86 . Causes related to contract's documents are placed in second ranking with a mean of 4.53 , other causes are in the last rank with mean of 2.37. Based upon results of this study, some recommendations are made in order to decrease and resolve claims in construction projects which mainly tries to limit differences. Some of the best methods to decrease or prevent delay in building projects are contractors' qualitative evaluation before tender process, projects resources allocation according to approved annual budget, is considered by many criteria such as 1) reasonable price offer, project's feasibility analysis, 2) timely payment of employees salary by employer, 3) timely decision making by employer in different steps of the project and 4) using experienced manpower in execution of construction project.

After comparing the results of this study with other researches, it is noticed that the current results have a high degree of similarity with much of the findings made by OudaAllah (2014). This researcher studied causes of construction project claims in Palestine - Gaza strip. This level of matching beside similar nature of construction projects leads to this conclusion that the sources of such claims could be exactly the same as other regions and countries.

\section{References}

Arditi, D. and Pattanakitchamroon, T. (2006). Selecting a delay analysis method in resolving construction claims. International Journal of Project Management, 24, 145-155.

Barrie, D. S. and Paulson, B. C. (1992). Professional construction management. New York: McGraw-Hill.

Bradley, S. and Langford, D. A. (1987). Contractor's claim, Build. Technol. And Mgmt.

Chang, Z. C. (2005). Construction claims analysis and application of research. Xi'an University of Architecture University of Science and Technology, Xi'an, China, 17-31.

Chaphalkar, N. B., Iyer, K. C., and Patil, S. K. (2012). Use of artificial intelligence techniques for construction dispute resolution - an overview. Int. J. Adv. Manag. Technol. Eng. Sci. 6, 115-120.

Chau, K. W. (2007). Application of a PSO-based neural network in analysis of outcomes of construction claims. Elsevier Autom. Constr. 16, 642-646.

Contracts and claims. (2011). Preparation and evaluation claims engineers trainingcentre. Amman, Jordan.

Diekman, J. and Nelson, E. (1985). Construction claims: frequency and severity .Journal of Construction Engineering and Management, 111 (1), 74-81.

Enshassi, A., Mohamed, S., and El-Ghandour, S. (2009). Problems associated with the process of claim management in Palestine: Contractors' perspective. Engineering, Construction and Architectural Management, 16 (1), 61-72.

Essam, K. Z. (2006). Construction claims in United Arab Emirates: Types, causes and frequency. International Journal of Project Management, 24, 453-459.
Hackett, J. and Dancaster, C. (2000). Construction claims: Current practice andcase management LLP, London.

Hassanein, A.G. and El Nemr, W. (2008). Claims management in the Egyptian industrial construction sector: A contractor's perspective. Engineering, Construction and Architectural Management, 15 (3), 246-259.

Iyer, K. C., Kalidindi, S. N., and Ganesh, L. S. (2002). Dispute prone contract clauses - a basis for operational flexibility in contract administration. Glob. J. Flex. Syst. Manag, 3, 39-51.

Kartam, S. (1999). Generic methodology for analyzing delay claims. J. Constr. Engrg. and Mgmt., ASCE, 125 (6), 409-419.

Kululanga, G., Kuotcha, W., McCaffer, R., and EdumFotwe, F. (2011). Construction contractors' claim process framework. Journal of Construction Engineering and Management, ASCE, 127 (4), 309314.

OudaAlloh, K. (2014). Investigating of factors causes claims creation in construction projects in the Gaza strip-Palestine. Thesis Submitted in Partial Fulfillment of the Requirement s for Degree of Master of Science in Construction Management.

Patil, B. S. (2005). Building and Engineering Contracts. Fifth ed. Mrs. S.B. Publication, India.

Pinnel, S. (1999). Partnering and managing construction disputes. Disput. Resolut. J, 54, 16-22.

Project Management Institute (PMI) (2010). Construction extension to a guide to the project management body of knowledge.

Qi, B. K. (2004). Trove of project management (second edition). Dalian University of Technology Press, Dalian.

Ren, Z., Anumba, C. J., and Ugwu, O. O. (2003). Multiagent system for construction claims negotiation. Journal of Computing in Civil Engineering, 17 (3), 180-188.

Sheikh S. J. A. A. S., Sami, M. F., and David, J. H. (2003). A database management system to document and analyse construction claims. Journal of Advances in Engineering Software, 34, 477-491.

Al-Sabah, S. S. J. A., Fereig, S. M., and Hoare, D. J. (2003). A database management system to document and analyse construction claims. Advances in Engineering Software, 34(8), 477-491.

Singh, P., Fook, C. Y., and Sidhu, G. K. (2006). A comprehensive guide to writing a research proposal. Batu Caves: Venton Professional.

Surawongsin, P. (2002). The implementation of construction claims management in the Thai construction industry. Master Thesis School of Civil Engineering Asian Institute of Technology (AIT), Pathumthani.

Vidogah, W. and Ndekugri, I. (1997). Improving management of claims: Contractors'perspective. Journal of Management in Engineering, 37-44.

$\mathrm{Yu}, \mathrm{W}$. R. (2009). Discussion engineering claims. Engineering Technology, Yancheng Institute of Architectural Engineering, 36, 234-235.

Zaneldin, E. K. (2006). Construction claims in United Arab Emirates: Types, causes, and frequency. International Journal of Project Management, 24, 453-459. 


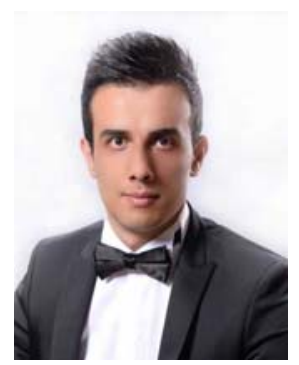

Bagher Dastyar is currently a project control manager at Iran Mall project and Teacher Assistant at Mehralborz University and Noor Toba University, Tehran. He received Bachelor's degree in Civil Engineering from the Shomal University, Amol, Iran and Master of Science degree in Construction Engineering and Management from Payam e Noor University, Karaj. He is engaged in teaching \& consulting in the fields of Civil Engineering, Construction, Project Management and etc. He has published more than fourteen papers in international conferences and presented many papers at national conferences. He is fluent in related software's in the field of planning and project controlling and civil engineering. His research interest is Project Management, Risk Management and Claim Management.

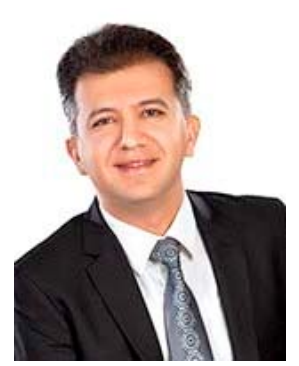

Amir Fakhrizadeh Esfahani is currently a project manager at 3 highways in north of province of Fars ,He graduated in the master of scince in the field of Construction Engineering and Management from AmirKabir University, Tehran .He is also engaged in Supervising two buildings in order to manage how the work is going in different part of work.. He is a member of Project Management Institute (PMI). He has ability to work under pressure and multitasking scenario, and Proficient in use of computers and software, Microsoft office, Primavera (p6), pert master (Risk Management), AutoCAD, and the Internet.

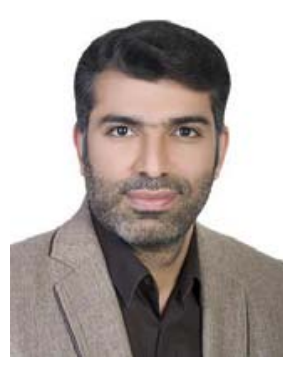

Madjid Askarifard is currently university lecturer in Mahallat (Province of Markazi), Now He is Ph.D Student in the field of Construction Engineering and Management in Azad University, Arak Branch .He is also official expert of justice in civil engineering from Supreme Council of Iranian Official Experts. He is a member of Iran Project Management Association (IPMA) and He has also license from Markazi Construction Engineering Organization in Supervision Section.He has 15 years experience in various Construction projects. He has ability to work Proficient in use of computers and software, Microsoft office, MSP, AutoCAD, and the Internet.

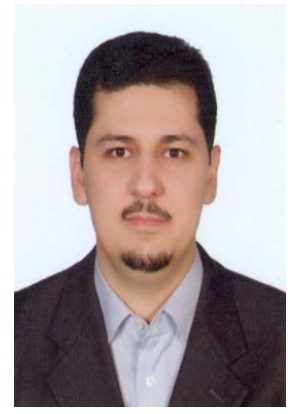

Dr. Armin Monir Abbasi is a professor assistant in Payam e Noor University. He graduated in the $\mathrm{PhD}$ degree of construction engineering and management in Iran University of Science and Technology (IUST). His research interest is Concrete Technology, Project Management, Risk Management and Claim Management. 